\title{
PENGEMBANGAN VIDEO PEMBELAJARAN PEMBUATAN SABUN HERBAL MINYAK ATSIRI KAYU MANIS
}

\author{
Yuni Tasmalina TE, Dwi Atmanto, Ernita Maulida \\ Universitas Negeri Jakarta, Indonesia \\ Email: ytasmalina@gmail.com
}

\begin{abstract}
ABSTRAK
Penelitian ini bertujuan untuk: 1) menghasilkan video pembelajaran tentang proses pembuatan sabun herbal dengan tambahan minyak atsiri kayu manis yang digunakan sebagai media pembelajaran; dan 2) menguji kelayakan video pembelajaran yang dihasilkan guna meningkatkan hasil belajar peserta didik pada mata kuliah Kimia Kosmetika. Video pembelajaran ini dimulai dari proses penyulingan kulit kayu manis hingga menjadi produk sabun herbal. Metode penelitian yang digunakan adalah metode penelitian dan pengembangan (R\&D) dengan model pengembangan gabungan antara model Borg \& Gall, Model Dick \& Carey dan Model Hannafin \& Peck. Prosedur pengembangan media meliputi tahap desain, pengembangan dan evaluasi. Teknik analisis data untuk uji coba produk menggunakan statistik deskriptif. Hasil penelitian sebagai berikut. (a) video pembelajaran sebagai media yang dikembangkan dinilai layak digunakan dalam pembelajaran ditinjau dari aspek media dan materi dengan skor penilaian ahli media 3,88 dan skor ahli materi 4,0 termasuk kategori sangat baik. (b) Multimedia pembelajaran pembuatan sabun ini dinilai efektif karena dapat meningkatkan pengetahuan dan keterampilan. Hal ini dibuktikan melalui hasil nilai pre-test aspek kognitif dengan rata-rata nilai 51,22 dan nilai post-test dengan rata-rata nilai 75,33, sedangkan pada ranah psikomotorik dengan rata-rata nilai 81,98. Dapat disimpulkan bahwa video pembelajaran yang dihasilkan tersebut layak dan tepat untuk meningkatkan hasil belajar peserta didik.
\end{abstract}

Kata Kunci: Video Pembelajaran, Sabun Herbal, Minyak Atsiri Kayu Manis

\section{ABSTRACT}

The purposes of this research are: 1) to produce learning videos about the process of making herbal soaps with the addition of cinnamon essential oil used as a learning medium; and 2) to test the feasibility of learning videos produced to improve learning outcomes of students in the Cosmetics Chemistry course. This learning video starts from the process of distilling cinnamon bark into a herbal soap product. The research is using research and development $(\mathrm{R} \& \mathrm{D})$ method with a joint development model between Borg \& Gall models, Dick \& Carey Models and Hannafin \& Peck Models. The procedure for media development includes the stages of design, development, and evaluation. The data analysis techniques conducted for product trials are using descriptive statistics. The results of the research are as follows: (a) the developed media are considered appropriate for use in learning process validated by media and material aspects by media expert assessment scores 3.88 and expert material scores 4.0, the scores are included in very good categories. (b) Multimedia learning for making soap is considered effective because it can increase knowledge and skills. The result is evidenced by the results of the cognitive aspect pre-test with an average value of 51.22 and post-test values with an average value of 75.33, while in the psychomotor domain is valued with an average value of 81.98 . It can be concluded that the learning videos produced are appropriate and appropriate for improving student learning outcomes.

Keywords: Learning Videos, Herbal Soaps, Cinnamon Essential Oil 


\section{PENDAHULUAN}

Pendidikan merupakan hal yang sangat penting bagi kemajuan negara dan sebuah negara yang maju akan menempatkan pendidikan sebagai prioritas pertamanya karena dengan pendidikan akan meningkatkan kesejahteraan rakyatnya (Megawanti, 2015:227). Perkembangan pendidikan di Indonesia senantiasa harus menghadapi masalah-masalah di setiap tahapnya dari mulai permasalahan kurikulum, biaya pendidikan, sarana pendidikan termasuk kurangnya media pembelajaran yang efektif untuk meningkatkan kualitas pendidikan. Akibat permasalahan tersebut maka kualitas pendidikan Indonesia mengalami penurunan. Hal ini dapat dilihat dalam laporan Human Development Report 2016 mencatat Indeks Pembangunan Manusia (IPM) Indonesia pada 2015 berada di peringkat 113, turun dari posisi 110 di 2016 (Badan Pusat Statistik, 2016). Dari data tersebut ini menunjukkan bahwa Indonesia termasuk negara berkembang dan masih di bawah negara-negara Asia lainnya seperti Singapura dan Malaysia. Hal ini menunjukkan pendidikan di Indonesia belum optimal pelaksanaannya dalam menunjang pembangunan bangsa (Nurnyata, 2010:45).

Penyebab rendahnya mutu pendidikan di Indonesia adalah (1) ketersediaan pendidik dan tenaga kependidikan yang belum memadai; (2) sarana dan prasarana belajar yang masih belum tersedia dan belum diberdayagunakan secara optimal; (3) pendanaan pendidikan yang belum memadai untuk menunjang mutu pembelajaran; serta (4) proses pembelajaran yang belum efektif dan efisien (Suryana, 2017:5). Pendidikan yang efektif dapat memungkinkan peserta didik untuk belajar dengan mudah, menyenangkan untuk mencapai tujuan yang diharapkan, sedangkan efesiensi adalah bagaimana meningkatkan efektivitas dari suatu tujuan pembelajaran dengan proses yang lebih mudah dan murah (Sya'diyah, 2013:5).

Mutu pendidikan dapat ditingkatkan dengan penggunaan media pembelajaran yang diharapkan dapat memperbaiki proses belajar mengajar sehingga pembelajaran dapat lebih efektif dan efisien, serta mendorong kreativitas peserta didik (Suprapto, 2006:41). Media pembelajaran tersebut menurut Gagne dan Briggs (1979) yang dikemukakan oleh Arsyad (2017:4) meliputi alat yang secara fisik digunakan untuk menyampaikan isi materi pengajaran berupa buku ajar, modul, foto, video, film, gambar, dan komputer yang saat ini sangat pesat penggunaannya dari mulai pendidikan dasar hingga perguruan tinggi.

Media pembelajaran yang dirancang dengan baik akan sangat membantu peserta didik mencapai tujuan pembelajaran dan dapat dijadikan sebagai wahana penyalur pesan dan informasi belajar (Nurseto, 2011:34). Media pembelajaran juga dapat mengkonkretkan sesuatu yang abstrak sehingga dapat menambah wawasan serta pengetahuan peserta didik guna memaksimalkan penyampaian materi pembelajaran. Materi yang biasanya hanya dibaca kini dapat dilihat melalui video sehingga memudahkan peserta didik untuk memahami materi dan dapat langsung mempraktikkannya. Media pembelajaran ini harus dibuat menarik sehingga materi yang disampaikan dapat diterima dengan baik dan bermanfaat sesuai dengan tujuan pembelajaran. 
Bagi peserta didik Program Studi Tata Rias UNJ, mata kuliah Kimia Kosmetika merupakan mata kuliah wajib yang harus ditempuh pada semester 4. Pada mata kuliah tersebut peserta didik dituntut untuk memiliki pengetahuan tentang bahan baku (alam dan kimia) pembuat kosmetik, percobaan pembuatan kosmetika dan reaksi kimia kosmetika pada kulit, kuku dan rambut. Materi ini mencakup: perkembangan kosmetika, reaksi kimia pada kulit, kimia rambut dan kuku, komposisi produk kosmetika dan fungsinya, campuran farmakologi dan bahan alam dalam kosmetika. Materimateri tersebut dapat diperoleh dari modul dan buku-buku teks yang ada.

Indonesia sejak dulu telah dikenal dengan sebutan negara megabiodiversitas (megabiodiversity) karena memiliki aneka sumber daya hayati yang berlimpah dengan berbagai keunikannya. Hal ini disebabkan karena banyak faktor seperti letak geografis, luas wilayah, dan iklim tropis. Indonesia menempati peringkat kedua dunia setelah Brasil dalam hal keanekaragaman hayati. Sebanyak 5.131.100 keanekaragaman hayati di dunia, 15,3\% nya terdapat di Indonesia. Pertanian dan perkebunan Indonesia menghasilkan produk yang mempunyai kualitas terbaik di dunia, diantaranya: kayu manis, teh, kopi, kakao, sirsak, jambu merah, dan manggis (Sudrajat, 2015).

Beberapa jenis tumbuhan tersebut dapat diproses untuk menghasilkan minyak dengan aroma yang khas dan dapat dimanfaatkan langsung maupun produk turunannya. Minyak ini disebut minyak atsiri yang saat ini tengah menjadi sorotan industri perawatan tubuh karena tidak hanya mampu menutrisi kulit dengan baik, tetapi juga ultraringan, cepat dan mudah meresap. Peran Indonesia sebagai sentra produsen atsiri dunia, menjadikannya sebagai wilayah yang strategis bagi industriawan atsiri. Sejarah menunjukkan sejak abad pertengahan, beberapa daerah di Sumatera khususnya Aceh, Padang yang sudah mengekspor berbagai komoditi atsiri dan rempah ke mancanegara. Ratusan jenis tanaman atsiri lainnya adalah nilam, kayu manis, cengkeh, pala, kenanga, ylang-ylang dan sereh wangi. Pertanaman kayumanis di Indonesia tersebar di 19 provinsi, terluas di Sumatera Barat dan Jambi terutama Kerinci $(80 \%)$ (Kemenperin, 2016).

Potensi pasar minyak atsiri yang besar masih belum dimanfaatkan di dalamnegeri, karenaindustridi Indonesia belum banyak yang dapat memproses lebih lanjut bahan dasar minyak atsiri tersebut menjadi atau produk yang memililiki nilai ekonomi yang lebih tinggi (Sastrohamidjojo, 2014:1). Produk turunan yang dibutuhkan oleh industri pangan, farmasi dan kosmetik dalam negeri masih diperoleh melalui impor.

Ekspor minyak atsiri Indonesia ke pasar dunia sebagian besar adalah produk langsung hasil penyulingan yang belum diolah menjadi turunannya yang bernilai lebih tinggi. Minyak atsiri sangat beragam dan digunakan antara lain dalam industri perisa (pangan), industri wewangian (sektor wewangian, perawatan diri, perawatan rumah), dan juga dalam industri kimia aromatik. Banyak minyak atsiri digunakan untuk memasak, pengharum ruangan, kerajinan, kosmetik, pijat, aromaterapi, dan penggunaan lainnya. Minyak atsiri lainnya digunakan untuk menolak 
serangga dan antropoda lainnya yang merupakan hama bagi manusia, ternak dan hewan peliharaan seperti nyamuk, kepinjal/flea, kutu/tick, dan serangga lain.

Salah satu minyak atsiri yang saat ini telah menjadi komoditas ekspor adalah minyak kayu manis. Pohon kayu manis merupakan tumbuhan asli Asia Selatan, Asia Tenggara dan daratan Cina, (Smith, 1986:85) Indonesia termasuk didalamnya. Dari 54 spesies kayu manis (Cinnamomum sp.) yang dikenal di dunia, 12 diantaranya terdapat di Indonesia. Dari kesemuanya, tiga jenis kayu manis yang menonjol di pasar dunia adalah Cinnamomum burmannii (di Indonesia) yang produknya dikenal dengan nama cassiavera, Cinnamomum zeylanicum (di Sri Lanka) dan Cinnamomum cassia (di Cina) yang produknya dikenal dengan Cassia Cina .

Ekspor kayumanis Indonesia mengalami peningkatan dalam kurun waktu lima tahun ini disebabkan makin beragamnya pemanfaatan kayumanis, terutama untuk kesehatan. Kulit kayumanis dalam bentuk asli seperti potongan dan bubuk dapat digunakan sebagai bumbu masakan daging dan ikan dan sebagai campuran dalam minuman (teh, kopi, kakao) (Ferry, 2013:12). Selain itu ekstrak kulit manis dapat menghambat pertumbuhan bakteri S.pyogenes dan E.Coli (Repi, 2016:4).

Semakin meningkatnya pengetahuan tentang pemanfaatan senyawa kimia yang terkandung dalam kayumanis menunjukkan bahwa kayumanis masih mempunyai potensi untuk berkembang dan meningkatkan pendapatan petani, devisa negara. Selain itu, tanaman kayumanis juga dapat berfungsi sebagai tanaman penghijauan dan konservasi lahan, khususnya di tebing-tebing dan kaki pegunungan serta daerah aliran sungai (Rusli, 1988:11).

Penggunaan kosmetik saat ini sudah semakin luas, salah satunya sabun yang merupakan kosmetik pembersih tertua sejak berabad-abad yang silam. Sabun adalah salah satu produk yang sangat penting serta diperlukan dalam kehidupan sehari-hari yang merupakan bahan pembersih. Sabun wajah khususnya harus mempunyai kandungan yang baik serta dapat memberikan perawatan pada kulit. Sabun tersebut dapat mengandung minyak atsiri yang tentunya mempunyai khasiat yang sangat baik, selain sebagai antibakteri juga tentunya dapat menghilangkan flek-flek atau bekas jerawat pada muka.

Gangguan pada kulit seperti permasalahan jerawat merupakan hal yang sangat mengganggu penampilan dan merupakan suatu penyakit atau radang yang mengenai susunan pil osebaseus pada kulit yang seringkali meninggalkan noda hitam atau flek hitam yang tentunya sangat mengganggu penampilan. Untuk itu diperlukan produk yang dapat digunakan dalam waktu yang panjang dan dapat mengobati jerawat dan menyamarkan noda hitam atau pada wajah. Produknya berupa sabun wajah herbal yang menggunakan bahan-bahan alami sebagai bahan bakunya seperti minyak kelapa dan minyak atsiri kayumanis.

Kayumanis memiliki kandungan senyawa eugenol $3,11 \%$ dan sinemaldehid $(90,24 \%)$ dan coumarin $(53,46 \%)$ (Hapsari, 2016), yang terbukti dapat mengurangi noda jerawat pada kulit wajah berminyak dan berpengaruh terhadap penipisan noda, luas noda dan kecepatan penghilang jerawat. (Rahayu, 2013). Selain itu kayumanis juga mengandung vitamin $\mathrm{C}$ yang berperan 
melindungi kulit dari pengaruh sinar buruk UV yang menyebabkan penuaan dini dan mencegah pembentukan melanin (Tranggono, 2007:120).

Pada mata kuliah Kimia Kosmetiks ini mempunyai Capaian Pembelajaran Mata Kuliah (CPMK) yaitu : (1) Menguasai konsep, teori dan prinsip bahan dasar kosmetika, (2) Menguasai konsep dan prinsip cara pembuatan kosmetika yang baik, (3) Menguasai formularium dan cara pembuatan kosmetik, sehingga diperlukan media pembelajaran yang dapat digunakan untuk memenuhi kompetensi tersebut sehingga tujuan pembelajaran dapat tercapai.

Media pembelajaran visual lebih sering digunakan karena apat menyampaikan pesan dengan lebih menarik, efisien (cepat dan nyata), dan efektif. Agar tujuan pembuatan video dapat tercapai, maka pembuatan naskah video harus terdapat ide atau pokok pikiran yang menjadi dasar dalam langkah selanjutnya.

Saat ini sabun herbal kayu manis sedang banyak peminatnya sehingga peserta didik diharapkan memiliki pengetahuan dan keterampilan untuk membuat sabun herbal kayu manis yang sangat baik manfaatnya. Untuk itu pada penelitian ini akan dikembangkan video pembelajaran tentang pembuatan sabun herbal kayumanis dari bahan mulai pengolahan kulit kayumanis menjadi minyak atsiri kayumanis hingga menjadi suatu produk sabun herbal, sehingga diharapkan dapat meningkatkan kompetensi peserta didik pada mata kuliah Kimia Kosmetika.

Perkuliahan Kimia Kosmetika saat ini menggunakan modul yang dibuat oleh dosen pengampu serta buku-buku teks yang ada di Perpustakaan IKK seperti bahan ajar, jurnal serta bukubuku penunjang lain. Jadi belum ada media lain selain modul dan buku. Oleh karena itu, video pembelajaran sangat diperlukan dan dipilih sebagai salah satu media pembelajaran tambahan pada mata kuliah ini karena dapat memberikan pengalaman yang nyata dalam industri penyulingan minyak. Selain itu video ini juga dapat memvisualisasikan materi sehingga peserta didik dapat merasa seperti berada pada lokasi penyulingan minyak atsiri dan seolah-olah ikut terlibat dalam pembuatan sabun herbal Dengan kata lain, materi pembelajaran dapat disampaikan secara dinamis (Daryanto, 2012:88).

\section{METODE}

Pada penelitian ini menggunakan metode penelitian dan pengembangan (Research \& Development) karena produk yang dihasilkan dari penelitian dapat membantu pelaksanaan pembelajaran pada mata kuliah Kimia Kosmetika, sehingga proses belajar dan mengajar akan semakin produktif, efektif dan efisien. Menguji keefektifan produk dapat dilakukan dengan uji coba untuk memperoleh sejumlah data dan informasi yang berfungsi sebagai masukan terhadap perbaikan produk. Dari hasil perbaikan tersebut akan didapatkan produk media pembelajaran yang layak dan berkualitas sehingga dapat dimanfaatkan oleh peserta didik.

Video ini akan dibuat dengan lokasi di CV. Pavettia Subang yang merupakan industri penyulingan minyak atsiri sebagai bakunya menggunakan kulit kayu manis yang diolah menjadi minyak atsiri kayumanis yang selanjutnya akan dijadikan tambahan untuk pembuatan sabun herbal. 
Pembuatan video ini dilakukan pada awal Februari 2018 dan selanjutnya akan diujicobakan pada materi perkuliahan Kosmetika Tradisional semester II Tahun Akademik 20172018 untuk peserta didik Program Studi Tata Rias Fakultas Teknik Universitas Negeri Jakarta. Jumlah peserta didik yang mengikuti perkuliahan tersebut sebanyak 120 orang (4 kelas @ 30 orang).
Dalam mengembangkan media pembelajaran ini, peneliti menggunakan prosedur dan langkah-langkah yang merupakan gabungan antara model Borg dan Gall, model Dick, Carey dan Carey, dan model Hannafin dan Peck. Prosedur dan langkah-langkah Teknik analisis statistik deskriptif tersebut digambarkan pada Gambar 1.

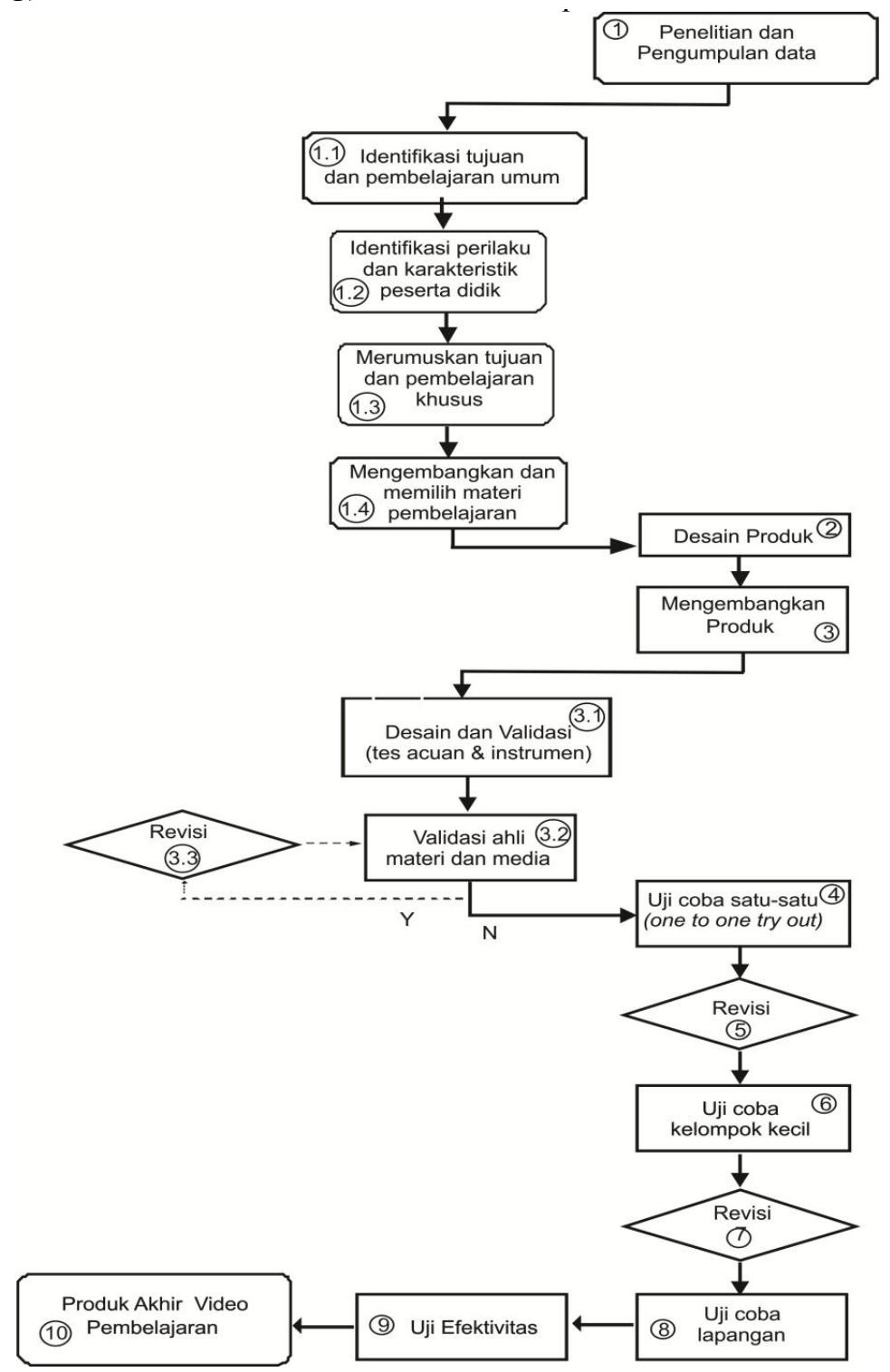

Gambar 1. Model Gabungan dari model Borg \& Gall, Model Dick, Carey \& Carey, dan Model Hannafin \& Peck.(Modifikasi dari model Borg dan (Borg \& Gall, 1983:772), Model Dick, Carey dan Carey (Uno, 2009:24), dan Model Hannafin dan Peck (Supriatna, 2009:15). 


\section{HASIL DAN PEMBAHASAN}

Penelitian

pendahuluan

dilaksanakan pada semester ganjil 2017/2018 melalui observasi dan wawancara informal kepada 15 orang mahasiswa Tata Rias yang telah mengambil mata kuliah tersebut pada semester yang lalu. Mahasiswa tersebut menyatakan bahwa selama ini materi perkuliahan disampaikan langsung oleh dosen pengampu dengan berbagai metode yaitu metode ceramah $(53,33 \%)$, diskusi $(13,33 \%)$ dan presentasi $(33,33 \%)$ melalui beberapa media yaitu modul $(33,33 \%)$ dan power point $(66,67 \%)$.

Dari wawancara tersebut dapat diperoleh informasi bahwa sebanyak 13 mahasiswa $(86,67 \%)$ menyatakan kesulitan memahami materi perkuliahan Kimia Kosmetika (S1). Kesulitan pemahaman materi perkuliahan disebabkan karena mahasiswa mempunyai kemampuan yang berbedabeda dalam memahami materi dan mempunyai latar belakang pendidikan SMA yang berbeda-beda (Penjurusan IPA dan IPS).

Modul perkuliahan yang tersedia juga kurang dimanfaatkan oleh mahasiswa dengan alasan malas dan kurang tertarik serta membosankan. Para mahasiswa juga belum pernah mendapatkan materi pembelajaran mata kuliah tersebut melalui media video dan menyatakan ketertarikannya dengan video pembelajaran, sehingga materi dapat diserap dengan baik.

Pada mata kuliah ini juga tidak ada materi praktikum sehingga mahasiswa tidak mempunyai nilai keterampilan. Para mahasiswa juga sangat antusias bila pada mata kuliah ini dapat mempraktikan materi yang telah didapatkan terutama pembuatan kosmetika sehingga mereka mempunyai tambahan pengetahuan tentang bahan-bahan dasar kosmetik dan tahapan pembuatannya. Output program studi Tata Rias adalah seorang praktisi kecantikan, perias pengantin dan seorang Make-up Artist (MUA) yang tentunya harus mempunyai pengetahuan dasar tentang kosmetika dari mulai bahan baku hingga proses pembuatannya. Sehingga perlu adanya tambahan pengetahuan melalui media lain tanpa melihat industri kosmetika secara langsung.

\section{Uji Kelayakan Media}

Kelayakan media pembelajaran tersebut dapat dilihat dari hasil validasi ahli maupun uji empirik terbatas, diantaranya :

Hasil penilaian program media pembelajaran oleh ahli media pembelajaran mendapatkan skor ratarata 3,68 berarti video tersebut dinilai baik, dengan penilaian beberapa aspek yang dapat dilihat pada Tabel 1 .

Pada bagian opening hendaknya ditambahkan tujuan pembelajaran sehingga mahasiswa yang menyaksikan video ini dapat mengetahui dengan pasti tujuan yang akan dicapai setelah menonton video. Selain itu pada bagian akhir video ini juga hendaknya ditambahkan kesimpulan yang diperoleh setelah menyaksikan video ini.

Hal ini dikarenakan masih ada noise pada beberapa bagian video karena pengambilan video ini di tempat industri penyulingan yang sedang melakukan kegiatan produksi, sehingga suara-suara dari luar sulit dihindari. Hal ini dapat diperbaiki melalui proses mixing audio sehingga noise dapat dikurangi. Volume suara presenter juga masih kurang konsisten, ada beberapa bagian yang terlalu kecil volumenya sehingga kurang 
terdengar dan dikhawatirkan dapat memberikan perbedaan interpretasi bagi yang menyaksikan video tersebut. Musik yang digunakan pada bagian opening memberi kesan alami dan menenangkan sedangkan pada bagian selanjutnya member kesan atraktif sehingga diharapkan meningkatkan semangat bagi yang menyaksikan video ini.

Terdapat beberapa bagian caption yang kurang sesuai kontras warna hurufnya. Hal ini dapat diperbaiki dengan mengedit bagian video sehingga hasilnya lebih maksimal. Jenis huruf dan ukuran yang digunakan pada caption juga sudah tepat karena seluruh huruf pada caption ini menggunakan jenis huruf Sans Sherif yaitu jenis huruf yang tidak memiliki garis kecil pada setiap akhir hurufnya.

Bahasa yang digunakan presenter telah sesuai dengan materi video, juga intonasi dan dialeknya. Hal ini karena presenter yang membawakan narasi ini memang seorang praktisi industri minyak atsiri yang telah berkecimpung selama kurang lebih 10 tahun. Materi yang disampaikan juga menggunakan bahasa yang ringan sehingga mudah dipahami dan diaplikasikan pada praktek pembuatan sabun.

Durasi video saat ini sekitar 19 menit, dirasa terlalu panjang karena kemungkinan akan mengurangi konsentrasi bagi mahasiswa yang menyaksikan video tersebut. Ada beberapa bagian video yang dapat dikurangidurasinya sehingga mahasiswa dapat dengan fokus menyaksikan video tersebut hingga selesai. Bagian video yang dikurangi tentunya hanya bagian yang kurang bermakna atau gerakan berulang sehingga tidak mengurangi materi dari video.

Menurut ahli media, video yang dihasilkan sudah semakin baik kualitasnya setelah direvisi, dan sudah memberikan peningkatan pada skornya. Terlihat bahwa skor rata-rata sebelum revisi adalah 3,68 sedangkan skor setelah revisi adalah 3,88 . Hal ini menyatakan bahwa perubahan yang dilakukan sudah sesuai dengan harapan sehingga media video ini sudah layak di uji coba lapangan tanpa revisi lagi.

\section{Hasil Penilaian Media oleh Ahli Media dan Materi}

\begin{tabular}{lccc}
\hline \multicolumn{1}{c}{ Aspek yang dinilai } & Ahli Media & $\begin{array}{c}\text { Ahli Media } \\
\text { (Revisi) }\end{array}$ & Ahli Materi \\
\hline Aspek Isi & 3,83 & 4 & 4 \\
Aspek Visual Media & 3,6 & 3,7 & 4 \\
Aspek Audio Media & 3,67 & 4 & 4 \\
Aspek Tipografi & 3,67 & 4 & 4 \\
Aspek Bahasa & 4,0 & 4 & 4 \\
Aspek Pemrograman & 3 & 4 & \\
Media & & & 4 \\
\hline
\end{tabular}




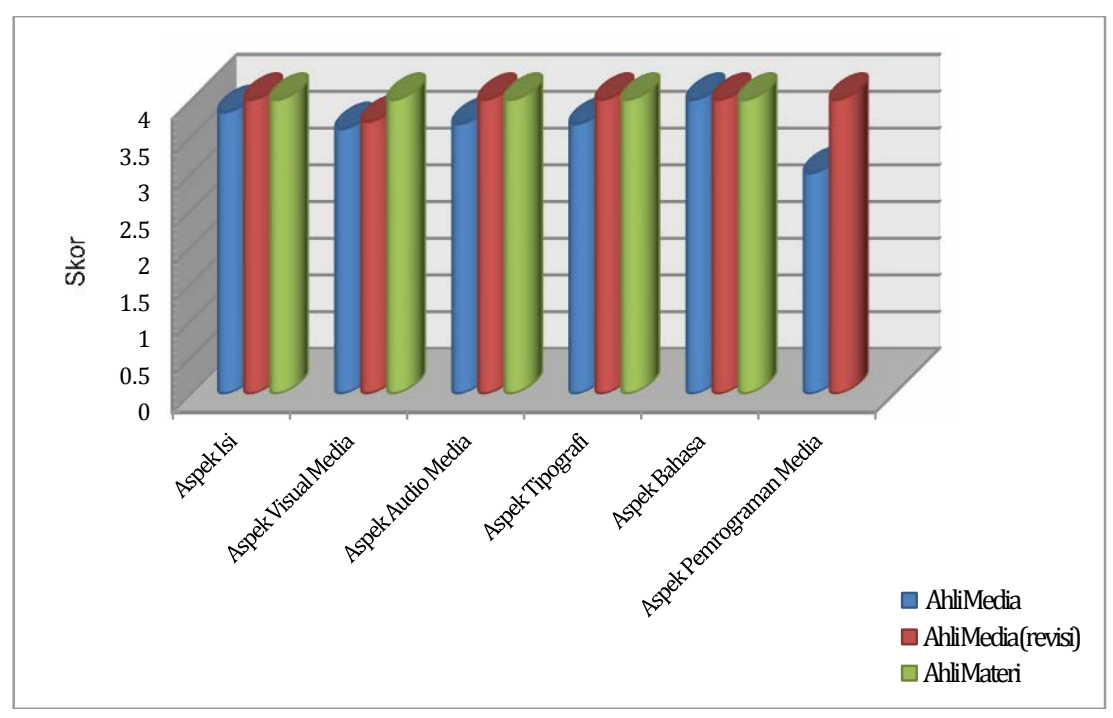

Gambar 2. Diagram Hasil Penilaian Media oleh Para Ahli

Hasil penilaian ahli materi pada media video ini adalah mendapat skor 4 yang berarti media video ini dinilai sangat baik (dapat dilihat pada tabel 1). Secara umum mengacu pada hasil penilaian ahli materi mengenai media pembelajaran yang dikembangkan dapat disimpulkan bahwa materi yang disajikan dalam video pembelajaran ini sangat baik. Bila dilihat dari segi materi, materi yang disajikan telah memadai dan memberikan pengetahuan serta pemahaman awal kepada mahasiswa terhadap materi pembuatan kosmetika yang dipelajari dan diaplikasikan pada mata kuliah Kimia Kosmetika di Program Studi Tata Rias Universitas Negeri Jakarta.

Menurut ahli materi, program video ini sangat menarik karena selama ini belum ada media pembelajaran untuk mata kuliah Kimia Kosmetika sehingga selama ini kesulitan dalam menyampaikan materi tersebut terutama dalam materi pembuatan kosmetika. Video ini juga dapat membantu sebagai petunjuk dalam praktik pembuatan kosmetika pembersih kulit dan wajah dalam hal ini sabun herbal. Dalam video ini juga dijelaskan mengenai proses penyulingan rempah (dalam hal ini kayumanis) menjadi minyak atsiri yang selanjutnya dapat diaplikasikan pada rempah-rempah atau tanaman lain yang sangat besar manfaatnya bagi bahanbahan kosmetika atau kecantikan.

Latar belakang video ini adalah pedesaan di daerah Subang yang masih 'hijau" dan subur sehingga memberikan kesan alami dan menyegarkan. Ketika menyaksikan video ini tidak terkesan sedang melihat materi pembelajaran yang sulit dan seakan-akan melihat suatu proses yang sederhana dan mudah dipahami. Mahasiswa dan masyarakat umum juga dapat menyaksikan video tersebut dan langsung mempraktekan proses pembuatan sabun dengan peralatan sederhana dan bahan-bahan yang mudah didapatkan, sehingga tujuan pembelajaran dari video ini dapat tercapai. Presenter memberikan penjelasan dengan pengucapan yang jelas sehingga mudah dipahami. Suara backsound juga dirasa tepat sehingga sangat mendukung materi yang disampaikan pada program video tersebut. 
Presenter juga menjelaskan proses penyulingan dengan detail dan dengan bahasa-bahasa yang ringan sehingga mudah dipahami, karena bila menggunakan bahasa yang terlalu "teknis" akan menimbulkan pertanyaan tersendiri bagi yang menyaksikannya. Tulisan (caption) juga sangat jelas dengan memperinci bagian-bagian dari alat penyulingan dan menjelaskan bahan baku pembuatan sabun, sehingga dapat lebih memperjelas makna dari gambar yang disajikan.

\section{Validitas Empiris}

Dalam penelitian ini dilakukan uji validitas empirik dengan :

a) Uji coba satu-satu (one to one try out)

Berdasarkan hasil evaluasi dan dan masukan dari para ahli selanjutnya adalah melakukan uji coba satu-satu kepada mahasiswa tata rias. Uji coba ini dimaksudkan untuk mengetahui kelayakan media pembelajaran dan dilakukan terhadap 3 orang mahasiswa tata rias. Mahasiswa diminta untuk mengamati, mencermati, mencatat dan mendiskusikan program video yang sedang dipelajari dan selanjutnya memberikan komentar dengan leluasa tentang media pembelajaran tersebut.

Berdasarkan informasi dari wawancara pada mahasiswa, maksud dan tujuan dari video tersebut dapat ditangkap dengan jelas. Para mahasiswa terlihat sangat antusis dalam menyaksikan video tersebut, bahkan sangat tertarik untuk selanjutnya mempraktekkan materi yang ada di dalam video tersebut, yaitu tentang pembuatan sabun.

b) Uji coba kelompok kecil (Small Group Try-out)

Setelah dilakukan revisi sesuai dengan masukan dan saran dari uji cobasatu-satu, maka dilakukan uji kelompok kecil dengan 19 orang mahasiswa. Uji coba ini bertujuan untuk mendapatkan informasi dan masukan dari mahasiswa mengenai media pembelajaran dan menekankan pada kejelasan dan keefektifan media pada setiap aspek yaitu mahasiswa .

c) Uji Coba Lapangan (Field Try-Out)

Uji coba lapangan ini bertujuan untuk mendapatkan informasi dan masukan dari mahasiswamengenaimedia pembelajaran dan juga menekankan pada keefektifan setiap aspek pada program media pembelajaran. Uji coba ini dilakukan pada mahasiswa yang sedang mengikuti perkuliahan Kima Kosmetika Program Studi Tata Rias UNJ sebanyak 82 orang. Secara umum pada tahap uji coba lapangan ini diperoleh hasil bahwa media pembelajaran yang dikembangkan dapat dikatakan baik dengan skor rata-rata keseluruhan 3,51 hal ini menunjukkan peningkatan dari hasil penilaian sebelumnya. Penilaian dari masing-masing aspek dan indikator yang dinilai adalah sebagai berikut : 
Tabel 2. Hasil Penilaian Pada Uji Coba Peserta Didik

\begin{tabular}{llccc}
\hline \multirow{2}{*}{ No } & \multicolumn{1}{c}{ Aspek yang dinilai } & $\begin{array}{c}\text { One to one } \\
\text { Try out }\end{array}$ & $\begin{array}{c}\text { Small Group } \\
\text { Try Out }\end{array}$ & $\begin{array}{c}\text { Field Group } \\
\text { Try Out }\end{array}$ \\
\hline A & Aspek Isi & 3,39 & 3,36 & 3,58 \\
B & Aspek Visual Media & 3,20 & 3,10 & 3,50 \\
C & Aspek Audio Media & 2,67 & 3,18 & 3,49 \\
D & Aspek Tipografi & 3,22 & 3,3 & 3,43 \\
E & Aspek Bahasa & 3,17 & 3,50 & 3,48 \\
F & Aspek Pemrograman Media & 3,33 & 3,32 & 3,48 \\
\hline & & 3,16 & 3,24 & 3,51 \\
\hline
\end{tabular}

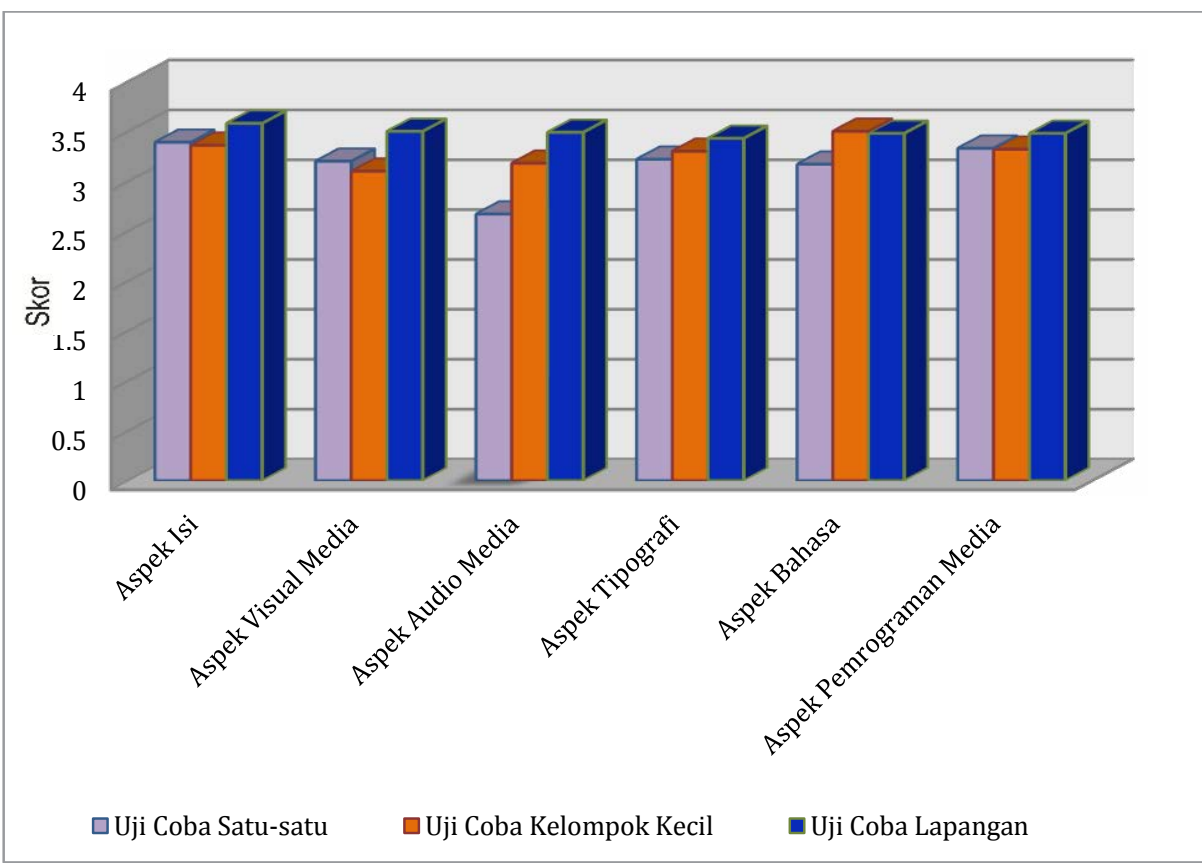

Gambar 3 Diagram Hasil Uji Coba Media oleh Peserta Didik

\section{Hasil Uji Coba Efektivitas Media Pembelajaran}

Uji coba lapangan dilakukan untuk mengetahui efektivitas media pembelajaran yang dikembangkan. Efektivitas ini dimaksudkan untuk membandingkan satu kumpulan pengukuran yang kedua dari contoh yang sama. Uji ini sering digunakan untuk membandingkan skor sebelum dan sesudah percobaan untuk menentukan apakah perubahan nyata telah terjadi.

Pretest dan postest pada penelitian ini dimaksudkan untuk mengetahui peningkatan hasil belajar setelah menggunakan media pembelajaran video yang dapat dilihat dari hasil belajar peserta didik. Hasil dari pretest ini menunjukkan bahwa materi pada media pembelajaran ini sangat dibutuhkan oleh mahasiswa untuk menambah pemahaman dan pengetahuan tentang penyulingan minyak atsiri dan juga pembuatan kosmetika dalam hal ini sabun herbal. Hal ini dapat disimpulkan dari skor yang didapatkan oleh 82 peserta didik yang mengikuti pretest untuk menilai ranah kognitif ini. Diperoleh skor 51,22 dan pencapaian tersebut dapat dikategorikan rendah.

Setelah mengerjakan pretest, mahasiswa diberi penjelasan untuk 
selanjutnya mengikuti pembelajaran dengan menggunakan media pembelajaran. Media ini dapat digunakan dengan bantuan laptop/dvd player dan TV yang disediakan. Petunjuk penggunaan media dapat pembelajaran dapat dipelajari pada lembar petunjuk penggunaan media pembelajaran yang dibagikan kepada mahasiswa.

Mahasiswa diberikan waktu selama dua kali pertemuan masingmasing 60 menit. Pertemuan pertama digunakan untuk mengerjakan pretest dilanjutkan dengan pemberian materi video pembelajaran dilanjutkan dengan wawancara kepada beberapa mahasiswa dan diskusi. Pada pertemuan berikutnya mahasiswa melakukan praktikum pembuatan sabun herbal sesuai dengan materi media pembelajaran. Pada akhir pertemuan ini mahasiswa diberikan Posttest juga diberikan penilaian pada ranah psikomotoriknya. Berdasarkan hasil posttest diperoleh skor sebesar 75,33 pada ranah kognitifnya. Perolehan angka ini dapat dikategorikan cukup dan menunjukkan peningkatan hasil belajar yang cukup besar hal ini memperlihatkan bahwa media video yang telah mereka pelajari telah memberikan tambahan pengetahuan dan wawasan bagi peserta didik. Sedangkan pada ranah psikomotorik memperoleh nilai 81,98 hal ini menunjukkan bahwa mahasiswa dapat mempraktikan materi video pembelajaran dengan baik tetapi tidak bisa dibandingkan dengan nilai pretest ranah psikomotorik. Karena adanya kesulitan untuk mengukur kemampuan sebelum praktek (pretest) atau ranah psikomotorik pada materi ini.

Berdasarkan metode perhitungan yang dilakukan dengan menggunakan rumus Wilcoxon Sign Rank Test.

Tabel 3. Uji Wilcoxon Sign Rank Test Test Statistics $^{\mathrm{b}}$

\begin{tabular}{lc}
\hline & Posttest - Pretest \\
\hline $\mathrm{Z}$ & $-7.785^{\mathrm{a}}$ \\
\hline Asymp. Sig. (2-tailed) & .000 \\
\hline
\end{tabular}

a. Based on negative ranks.

b. Wilcoxon Signed Ranks Test
Hipotesis:
$\mathrm{H} 0: \mu=0$ (tidak ada perbedaan nilai pretest dan post test)
$\mathrm{H} 1: \mu \neq 0$ (ada perbedaan nilai pretest dan postest)
Tingkat signifikansi $\alpha=0,05$

Berdasarkan hasil dari perhitungan Wilcoxon Signed Rank Test, maka nilai $Z$ yang didapat sebesar -7,785 dengan $\mathrm{p}$ value (Asymp. Sig 2 tailed) sebesar 0,000 di mana kurang dari batas kritis penelitian 0,05 sehingga keputusan hipotesis adalah menerima $\mathrm{H} 1$ atau yang berarti terdapat perbedaan bermakna antara kelompok pretest dan postest. Secara umum dapat disimpulkan bahwa media pembelajaran yang dikembangkan ini efektif dalam rangka pencapaian kompetensi mahasiswa. 


\section{SIMPULAN}

Penelitianinitelahmengembangkan media pembelajaran melalui tahapan penelitian dan pengembangan dan dapat disimpulkan sebagai berikut: Proses pembuatan video pembelajaran telah melewati tahapan meliputi identifikasi kompetensi, desain produk, pembuatan video dan audio, desain dan validasi tes acuan \& instrument, tinjauan ahli, revisi model (draft 1), uji coba terbatas kepada mahasiswa, revisi model (Draft 2), dan produk akhir.

Berdasarkan hasil pengujian dan pembahasan penilai yang diberikan oleh ahli media adalah sebesar 3,88 dan menurut ahli materi sebesar 4 . Sedangkan penilaian yang didapatkan dari mahasiswa sebesar 3,51 hal ini menunjukkan bahwa media yang telah dikembangkan ini sangat baik dan layak digunakan sebagai alternatif media pembelajaran.

Pada penilaian ranah kognitif diperoleh nilai rerata nilai pretest sebesar 51,22 dan post test sebesar 75,33 yang menunjukkan adanya peningkatan hasil belajar mahasiswa setelah menggunakan media pembelajaran tersebut. Sedangkan pada ranah psikomotorik mahasiswa dinilai keterampilannya sebagai aplikasi materi video yang telah diperoleh sebesar 81,98. Secara umum media pembelajaran pembuatan sabun herbal yang dihasilkan dapat meningkatkan hasil belajar mahasiswa tentang pembuatan kosmetika bahkan dapat membangkitkan minat mahasiswa untuk membuat kosmetika terutama dengan tambahan bahan-bahan alami sehingga diperoleh produk kosmetika yang aman dan berkualitas.

Berdasarkan kesimpulan diatas maka terdapat beberapa saran untuk kemajuan penelitian berikutnya, yaitu
: Penelitian selanjutnya diharapkan menghasilkan produk dalam bentuk interaktif multimedia berbasis teknologi informasi sehingga mahasiswa dapat langsung berinteraksi dengan media tersebut (dua arah), sehingga proses pembelajaran dapat lebih efisien dan dapat diakses di berbagai tempat (online) tanpa ada batasan waktu. Peningkatan fasilitas dalam penerapan media pembelajaran hendaknya dilakukan sehingga media pembelajaran yang telah dikembangkan dapat dimanfaatkan secara langsung oleh mahasiswa dan masyarakat.

\section{DAFTAR PUSTAKA}

Arsyad, Azhar. 2017. Media Pembelajaran. Jakarta : Rajawali Pers

Badan Pusat Statistik. 2016. Indeks Pembangunan Manusia Tahun 2016 (http://www.bps.go.id), diakses 23 Oktober 2017.

Daryanto. 2012. Media Pembelajaran. Bandung : Satu Nusa

Megawanti, Priarti. 2015. Meretas Permasalahan Pendidikan di Indonesia. Jurnal Formatif 2(3): 227-234. ISSN: 2088-351X.

Nuryata, Made. 2010. Pembelajaran Masa Kini. Jakarta : Sekarmita Suyanto, 2002. Pendidikan untuk Masyarakat Indonesia Baru. Tantangan Global Pendidikan Nasional. Jakarta : Grasindo

Nurseto, Tejo. 2011. Membuat Media Pembelajaran yang Menarik. Jurnal Ekonomi dan Pendidikan. Volume 8 No.1, April 2011.

Sudrajat, Ilyani, 2015. 7-hasil-pertanianindonesia-kualitas-terbaik-dunia (dikunjungi: 29 September 2017 dari https://www.kompasiana. com/ilyani) 
Suprapto, 2006. Peningkatan Kualitas Pendidikan Melalui Media Pembelajaran Menggunakan Teknologi Informasi di Sekolah. Jurnal Ekonomi \& Pendidikan, Volume 3 No.1, April 2006, Halaman 34-41.

Supriatna, Dadang dan Mochamad Mulyadi. 2009. Konsep Dasar Desain Pembelajaran. Jakarta: Pusat Pengembangan dan Pemberdayaan Pendidik dan Tenaga kependidikan Taman Kanak Kanak dan Pendidikan Luar Biasa.
Suryana, 2017. Permasalahan Mutu Pendidikan dalam Perspektif Pembangunan Indonesia. Juornal Universitas Semarang.

Sya'diyah, Halimatus, 2013. Kacaunya Pendidikan di Indonesia., Jurnal Ilmiah, Jurusan Kurikulum dan Teknologi Pendidikan Fakultas Ilmu Pendidikan, Universitas Negeri Semarang.

Uno, Hamzah, 2009. Model Pembelajaran Menciptakan Proses Belajar Mengajar yang Kreatif dan Efektif. Jakarta: PT Bumi Aksara. 